\title{
The impact of catchment source group classification on the accuracy of sediment fingerprinting outputs
}

\author{
Simon Pulley ${ }^{1,2}$, Ian Foster ${ }^{1,2}$, Adrian L. Collins ${ }^{3}$
}

${ }^{1}$ Rhodes University: Geography Department, Rhodes University, Eastern Cape 6140, South Africa.

${ }^{2}$ The University of Northampton: School of Science and Technology, University of Northampton, Northampton, NN2 6JD, UK.

${ }^{3}$ Sustainable Soils and Grassland Systems Department, Rothamsted Research, North Wyke, Okehampton EX20 2 SB, UK.

Corresponding author: Simon Pulley. Email: s.pulley@ru.ac.za

\begin{abstract}
The objective classification of sediment source groups is at present an under-investigated aspect of source tracing studies, which has the potential to statistically improve discrimination between sediment sources and reduce uncertainty. This paper investigates this potential using three different source group classification schemes.

The first classification scheme was simple surface and subsurface groupings (scheme 1). The tracer signatures were then used in a two-step cluster analysis to identify the sediment source groupings naturally defined by the tracer signatures (scheme 2). The cluster source groups were then modified by splitting each one into a surface and subsurface component to suit catchment management goals (scheme 3). The schemes were tested using artificial mixtures of sediment source samples. Controlled corruptions were made to some of the mixtures to
\end{abstract}


mimic the potential causes of tracer non-conservatism present when using tracers in natural fluvial environments. It was determined how accurately the known proportions of sediment sources in the mixtures were identified after unmixing modelling using the three classification schemes.

The cluster analysis derived source groups (2) significantly increased tracer variably ratios (inter- / intra-source group variability) (up to $2122 \%$, median 194\%) compared to the surface and subsurface groupings (1). As a result, the composition of the artificial mixtures was identified an average of $9.8 \%$ more accurately on the $0-100 \%$ contribution scale. It was found that the cluster groups could be reclassified into a surface and subsurface component (3) with no significant increase in composite uncertainty (a $0.1 \%$ increase over scheme 2 ). The far smaller effects of simulated tracer non-conservatism for the cluster analysis based schemes $(2$ and 3) was primarily attributed to the increased inter-group variability producing a far larger sediment source signal that the non-conservatism noise (1). Modified cluster analysis based classification methods have the potential to reduce composite uncertainty significantly in future source tracing studies.

Keywords: Sediment fingerprinting; Sediment sources; Discrimination, Tracing, Uncertainty

\section{Highlights:}

- Robust discrimination between sediment sources is essential for fingerprinting

- Source groups were classified according to management goals and tracer signatures

- Objective classification reduced intra- and increased inter-group variability

- Objective classification significantly reduced uncertainty in unmixing model outputs

- The impacts of tracer non-conservatism were reduced with objective classification 


\section{Introduction}

Sediment fingerprinting has become a key method of determining the importance of the sediment sources in a catchment (e.g. Collins et al. 2010a). However, several methodological uncertainties associated with existing fingerprinting procedures have been highlighted in recent publications (D’Haen et al. 2012; Koiter et al. 2013; Smith and Blake, 2014; Laceby and Olley, 2015; Pulley et al. 2015a \& b). Establishing a robust discrimination between sediment sources using suitable tracers is a key recommendation for accurate source tracing (Collins and Walling, 2002), making it a goal of many sediment fingerprinting based studies.

A fairly robust discrimination between different land uses as well as subsurface (i.e. streambank) sources has been established using some tracers. For example, ${ }^{137} \mathrm{Cs}$ or excess ${ }^{210} \mathrm{~Pb}$, where the mixing of tracer fallout through the soil profile during ploughing results in lower activities in cultivated land in comparison to undisturbed grassland or woodland (Walling and Woodward, 1992). Additionally, very low activities would be expected in subsurface sources, which are not exposed to direct fallout (Collins and Walling, 2002; Walling, 2004). However, fallout radionuclides (i.e. ${ }^{137} \mathrm{Cs}$ ) my not produce ideal source identification in many catchments. For example, robust discrimination might be limited in many catchments if channel banks are composed of displaced surface material or floodplain deposits (with ages $>1950$ 's), which has high activities (Walling, 2003). Alternatively, where environmental factors only support shallow channel banks comprising surface soils rather than well-developed vertical faces and processes of diffusion, bioturbation and eluviation cause migration of ${ }^{137} \mathrm{Cs}$ down through the soil profile (Walling and Woodward 1992; Walling, 2003; Mabit et al., 2008), or where agricultural rotation between arable crops and short-term ley or untilled grass reduces the distinction between cultivated and undisturbed 
surface soils (Smith and Blake, 2014). As a result, there is often incomplete discrimination between sediment source using ${ }^{137} \mathrm{Cs}$, or similarly, excess ${ }^{210} \mathrm{~Pb}$ (e.g. Collins et al. 2001; Collins et al. 2007; Smith and Blake 2014). Because of this, it is common practice that ${ }^{137} \mathrm{Cs}$ and many other individual tracers are utilised in a composite fingerprint consisting of many tracers, to help avoid spurious source-sediment matches (e.g. Stanton et al. 1992; Collins et al. 2013). Due to the complex nature of the dynamics of most tracers in the environment, the basis for source discrimination of many of the tracers utilised in composite fingerprints is rarely understood, and instead, a 'black box' type methodology is commonly used, which has been criticised (Koiter et al. 2013; Smith and Blake, 2014).

A review by Haddadchi et al. (2013) shows that it is currently practice to classify sediment source groups by land use (including surface/ subsurface sources) in the vast majority of sediment fingerprinting research (Slattery et al. 1995; Walling and Woodward, 1995; Collins et al. 2010a; Collins et al. 2010b; Smith and Blake, 2014). This is despite the fact that the majority of catchments investigated in source tracing studies will contain heterogeneous geology or soil types. For example, Pulley et al. (2015a), Collins et al. (2013), Smith and Blake (2014), Wilkinson et al. (2013), Palazón et al. (2015), Nosrati et al. (2014), Evrard et al. (2013) and Gellis et al. (2009) have all recently published source tracing studies in catchments with heterogeneous geology and/or soil. This potentially represents a problem if the signal of different land use is weakly expressed by the tracers used. Horowitz and Stephens (2008) investigated the impact of land use on the chemistry of river sediment in a large scale study of 51 river basins across the USA, with drainage areas ranging from 28 to $49,800 \mathrm{~km}^{2}$. It was found that the only land use to have a significant effect on sediment chemistry was urban areas. Therefore, the geochemical signal of land use (and subsurface sources) in river sediments may possibly be very weak. In contrast, the signal of geology or soil type may often be very strong. For example, with the dissolution of magnetic iron oxides 
which can take place in anoxic and reducing soil conditions (Anderson and Rippey, 1988; Roberts and Turner, 1993), or highly different tracer concentrations in different geological units (Collins et al., 1998; Owens et al. 1999; Pulley et al. 2015c) or spatially variable anthroprogenic tracer inputs (Devereux et al. 2010; Rossini et al. 2010; Guieu et al. 2010). These factors are likely to result in land use classified source groups with a very large amount of within-group variability. The effect of a large within-source group variability is to significantly increase uncertainty associated with source apportionment results (Small et al. 2002; Collins et al., 2010; Pulley et al. 2010a).

The impacts of tracer non-conservatism caused by factors such as organic matter (Wang et al. 2010; Carr et al. 2010; Nadeu et al. 2011) and particle size (Elrick 1987; Motha et al. 2003; Pye et al. 2007; Pulley et al. 2015c) may also be increased when a small difference in tracer concentration exists between source groups. For example, if there is only a $10 \%$ difference in the mean tracer concentration of two source groups and non-conservatism causes a 5\% change to a tracer during sediment transport, very large errors will be present in the final outputs. Alternatively, if a $100 \%$ difference exists between tracer signatures in the source groups, a 5\% change caused by non-conservatism during sediment mobilisation, intermediate storage and delivery will only have a minor impact on source fingerprinting estimates.

A method which could potentially reduce within-source group variability and increase intragroup variability was developed by Walling et al. (1993) who used pre-selected tracers in a cluster analysis to classify sediment source groups. It was found that land use was the primary controlling factor on tracer signatures and classified 4 to 6 source groups. Walling and Woodward (1995) also used this method and geology was identified as the major controlling factor controlling source group classification. Using this method of source classification provides the benefit that the natural variability in tracer concentrations within a catchment is used to define the source groups; therefore, each source group should have a low 
within-group variability in tracer concentrations and be substantially different to other groups. Despite these clear advantages, this method of source group classification has largely been neglected in recent literature. It is likely that catchment management goals such as identifying sediment inputs from a specific source such as eroding farm tracks (Collins et al. $2010 \mathrm{~b}$ ) have necessitated the prior selection of source groups without regard to the natural variability in tracers within a catchment.

The overall question this paper aims to answer is: can the objective classification of sediment source groups using an updated cluster analysis based method reduce gross uncertainty in fingerprinting outputs? Additionally, can we modify the cluster analysis derived source groups to suit management goals; in this example discriminating between surface and subsurface sources, while maintaining the benefits of the cluster analysis method.

This study uses artificial mixtures of sediment source samples, some of which are deliberately corrupted by numerous means to test the accuracy of unmixing model results when the different source group classification methods are used. Error evaluation using artificial mixtures has been increasingly adopted as a routine component of sediment source tracing studies (e.g. Palazón et al. (2015).

\section{Study area}

The sediment source samples were retrieved from the largest tributary sub-catchment (4.3 $\mathrm{km}^{2}$ ) of Sywell Reservoir, which is located in the Nene river basin in the East Midlands of the UK. The catchment is composed of Jurassic age mudstones and sand and ironstones in the lower catchment as well as Quaternary diamicton in the upper catchment (Figure 1). Soils in the catchment are a combination of freely draining brown earths in the lower catchment over 
the ironstone geology and poorly draining clayey soils in the upper catchment. The land use is predominantly cultivated land (54.4\%) used for wheat production with some areas of improved grassland (22.7\%) which are used for sheep grazing, as well as woodland $(22.7 \%)$ (Figure 1; Morton et al. 2011). The River Nene basin has an average annual rainfall of 638 $\mathrm{mm}$ recorded at Althorp over the last 140 years according to records transcribed by the authors from the UK Met Office archives. Construction of Sywell reservoir was completed in 1906, and an area of wetland has developed in alluvial deposits where the river enters the reservoir close to sampling points 1 and $1 \mathrm{~b}$ (Figure 1). Very little erosion of toposils was observed in the study catchment, with a single small area of cultivated land appearing to have undergone some minor rill erosion. Channel banks were observed to have slumped and be exposed to fluvial entrainment in many areas. A previously published fingerprinting investigation in the River Nene basin by Pulley et al. (2015a) identified that there were large differences $(24 \%)$ between the provenance predictions made by different sediment tracer groups when tracing using land use source categories. Therefore, the Nene basin represents a challenging environment for the successful application of robust sediment source fingerprinting. 


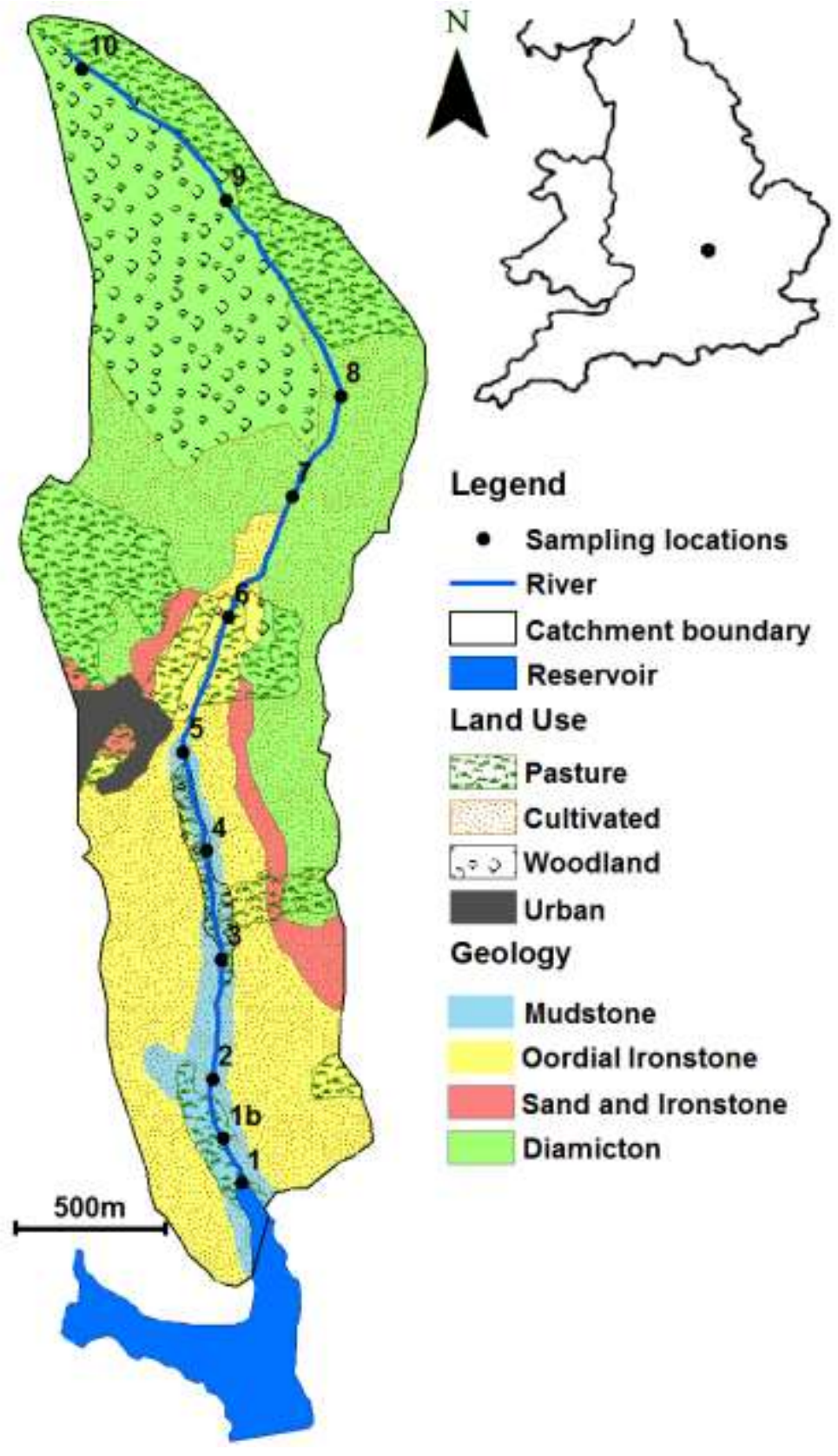

Figure 1: The geology and land use in the study catchment (after Morton et al 2011; British Geological Survey 2011) and the locations of sediment source sampling points.

\section{Methods}

\subsection{Sediment source sampling and laboratory analyses}


Sediment source samples were collected from 11 locations along the rivers channel banks (Figure 1). Samples were only collected from the bank material and topsoils directly above it as this study aimed to investigate different source classification methods comprising two fundamental source categories (surface and subsurface) to simplify the interpretation of results.

At each sampling point, 2 to 10 samples of the channel bank material were collected at 10 to $15 \mathrm{~cm}$ intervals down the exposed channel bank face according to vertical stratigraphy; using a non-metallic knife after 5 to $10 \mathrm{~cm}$ of superficial material had been removed in order to minimise contamination by mass failure surface drapes and flood deposits. The sampling locations were selected primarily on the basis of the presence of exposed banks with a lack of vegetation and accessibility and to be roughly evenly spaced along the entire channel network length. An additional sample of topsoil was collected using a non-metallic trowel to a depth of $5 \mathrm{~cm}$ from each sampling location in the cultivated or grass fields located past the riparian zone and outside of the limits of any floodplain ( $\sim 10 \mathrm{~m}$ from the river channel). Each sample was an individual sample and not a composite of multiple samples. A total of 58 subsurface channel bank samples and 20 surface samples (the top $5 \mathrm{~cm}$ of the banks and nearby field topsoils) were collected. Each sample was oven dried at $40^{\circ} \mathrm{C}$ for 24 hours before being sieved to $<63 \mu \mathrm{m}$ to conform to common practice in published fingerprinting studies (e.g. Walling et al., 1993; Walling and Woodward, 1995; Collins et al., 1997, 2010a).

Mineral magnetic (Walden et al. 1997), geochemical (Collins et al. 2010a) and colour signatures (Pulley and Rowntree, 2016) were measured as potential sediment source tracers.

Mineral magnetic signatures were measured using 8 to $10 \mathrm{~g}$ of each sample tightly packed into $5 \mathrm{ml}$ polystyrene sample pots. The properties shown in Table 1A were measured using the methods described by Lees (1999). The repeat measurement of six samples for five 
repetitions identified that a mean error (coefficient of variation; \%) of 5.3\% was associated with the measurement of magnetic tracers.

Geochemical tracers were measured using $0.8 \mathrm{~g}$ of each sample digested in $10 \mathrm{ml}$ of aqua regia at $180^{\circ} \mathrm{C}$ for 20 minutes in a CEM Mars 6 digestion unit. The concentrations of $\mathrm{Al}, \mathrm{B}$, $\mathrm{Ba}, \mathrm{Ca}, \mathrm{Cu}, \mathrm{Fe}, \mathrm{K}, \mathrm{Li}, \mathrm{Mg}, \mathrm{Mn}, \mathrm{Mo}, \mathrm{Ni}, \mathrm{P}, \mathrm{Pb}, \mathrm{S}, \mathrm{Sr}, \mathrm{V}, \mathrm{Y}, \mathrm{Zn}$ and $\mathrm{Zr}$ were determined using a Thermo Scientific iCAP 6500 dual view ICP-OES. The repeat measurement of samples identified that a mean error (coefficient of variation; \%) of $11.6 \%$ was associated with the measurement of geochemical tracers.

Colour signatures were measured using the prepared samples packed into polythene bags. Images of the source material were captured using a Lexmark x2650 colour scanner and were imported into Gimp 2 open source image editing software. The mean intensity of reflected red, green and blue light was recorded on the 0-255 scale of the RGB colour model. The colouration indices shown in Table 1B were then calculated using the extracted RGB values. The methods used for measurement are discussed in more detail by Pulley and Rowntree (2016). The repeat measurement of samples identified that a mean error (coefficient of variation; \%) of $4.1 \%$ was associated with the measurement of colour signatures.

Table 1. The magnetic properties (Maher, 1988 Walden, 1999; Yang et al. 2010; Wang et al. 2012) and colour signatures (Ray et al. 2004; Viscarra Rossel et al. 2006) used, their calculation and the property they represent. All measurements were initially performed on the $<63 \mu \mathrm{m}$ fraction.

\begin{tabular}{cccc}
\hline Name & Calculation & Property & Instrument
\end{tabular}

\section{(A) Magnetic signatures}

Low frequency susceptibility $(\chi \mathrm{lf})$ 
Frequency dependent susceptibility $(\chi \mathrm{fd})$

Susceptibility of anhysteretic ( $\chi$ arm) remanance magnetisation

Saturation isothermal remanence magnetisation (1T) (SIRM)

Back isothermal remanence magnetisation (-100mT) (IRM$100)$

Hard isothermal remanence magnetisation (HIRM)

\section{(B) Colour signatures}

Red

Green

Blue

HRGB

IRGB

SRGB

Saturation

Index

Hue Index

Coloration Index

Redness Index $\left(\left(\chi_{\mathrm{lf}}-\chi_{\mathrm{hf}}\right) / \mathrm{m}\right) \times 100$

$(\mathrm{m}=$ sample mass $)$

ARM x $3.14 \times 10$

stable single domain ferrimagnetic grains in the 0.02 to $0.4 \mu \mathrm{m}$ range

Raw data

Raw data

$\mathrm{IRM}_{1 \mathrm{~T}} /(1-(1 \mathrm{x}$

(IRM-100mT / IRM

1T)))/2

Raw data

Raw data

Raw data

$\underline{(2 \mathrm{xG})-\mathrm{R}-\mathrm{B}} 4$

$\underline{\mathrm{R}}+\mathrm{G}+\mathrm{B}$

3

$\underline{\mathrm{R}-\mathrm{B}}$

$\underline{(\mathrm{R}-\mathrm{B})}(\mathrm{R}+\mathrm{B})$

(2xR-G-B) (G-B)

$\underline{(\mathrm{R}-\mathrm{G})}(\mathrm{R}+\mathrm{G})$

$\underline{\mathrm{R}^{2}}$

$\left(\mathrm{BxG}^{3}\right)$
Almost all remanence carrying minerals

The majority of single domain ferromagnetic grains

High coercivity canted antiferromagnetic minerals or coarse multidomain ferromagnetic grains

Reflected red light

Reflected green light

Reflected blue light

Hue

Light

intensity

Chromatic information

Spectra slope

Primary colours

Soil colour

Hematite content
Bartington Instruments MS2b sensor

Molspin ${ }^{\circledR}$ anhysteretic remanent magnetiser; Molspin ${ }^{\circledR}$ slow-speed spinner magnetometer

Molspin ${ }^{\circledR}$ pulse magnetiser, Molspin ${ }^{\circledR}$ slow-speed spinner magnetometer

Molspin ${ }^{\circledR}$ pulse magnetiser Molspin $\AA$ slow-speed spinner magnetometer

Calculated

Lexmark x2650

Lexmark x2650

Lexmark x2650

Calculated

Calculated

Calculated

Calculated

Calculated

Calculated

Calculated

\subsection{Sediment source group classification methods}


The source samples collected were classified into different sediment source groups for tracing in the following three ways:

1: The simple method of classification into two fundamental groups; surface (topsoils $0-5 \mathrm{~cm}$ depth) and subsurface (i.e. channel banks) sources.

2: A two-step cluster analysis based upon the methods of Walling et al. (1993) and Walling and Woodward (1995) was used in SPSS 20 to determine the sediment source groups which best fitted the measured tracer signatures. Prior to the cluster analysis, the tracer signatures were included in a principal component analysis with varimax rotation in SPSS 20 to identify the tracers most strongly correlated with each principal component in the source samples. This was undertaken to simplify the variables input into the cluster analysis. The two-step cluster analysis was repeated with between 2 and 6 clusters and the solution with the best silhouette coefficient (the smallest mean between-cluster distance minus the mean withincluster distance, divided by the larger of the two distances) was used to define the catchment source groups. This measure represents how well separated each cluster is from other clusters and how closely related the data points in any individual cluster are.

3: The third method of source classification was to reclassify the surface and subsurface sources of each cluster group (from method 2) into separate source groups. This classification method was aimed at retaining the naturally present cluster groups while fully accommodating the catchment management goal of discriminating between surface and subsurface sources for the purpose of targeting sediment control strategies.

\subsection{Creation of the artificial mixtures of sediment sources}


The effectiveness of each of the three source group classification methods at reducing uncertainty in the unmixing outputs was tested using artificial mixtures of the channel bank and topsoil samples. Each mixture was created with known proportions of each sediment source group derived using the three classification methods, these were generated only after applying the cluster analyses and discriminant analysis. An equal mass of sediment from each source sample collected which was in each group was used unless otherwise specified. Some mixtures were deliberately corrupted in the ways shown in Table 2 in an attempt to replicate potential ways in which the non-conservatism of tracers might occur in the natural environment. Three repetitions for each mixture were unmixed, composed of the following proportions of surface and subsurface sources: $0.25: 0.75,0.50: 0.50$ and $0.75: 0.25$ (these were converted into the proportions in the source groups derived using methods 2 and 3 by knowing which group the individual source samples added to the mixtures were classified into). The overall question asked when fingerprinting each mixture is "how close to the actual proportions of sediment in the artificial mixtures are the fingerprinting results derived using the different classification methods?".

For the deliberately corrupted mixtures, the prepared mixtures were wet sieved through a 38 $\mu \mathrm{m}$ stainless steel mesh using ultrapure distilled water and the $63-38 \mu \mathrm{m}$ and $<38 \mu \mathrm{m}$ fractions retained for tracing. When organic matter was added, cotton wool (as organic matter of a uniform composition) was reduced to a powder using a blender and the appropriate mass added to each mixture.

Table 2: The artificial sediment source mixtures created and their purpose.

\begin{tabular}{ll}
\hline Mixture & Purpose \\
\hline All channel bank and surface sources & $\begin{array}{l}\text { How does source group classification change the } 5^{\text {th }} \text { to } 95^{\text {th }} \text { range of } \\
\text { uncertainty produced by the Monte Carlo based unmixing model as well } \\
\text { with no corruption }\end{array}$ \\
$\begin{array}{l}\text { as the error resulting from measurement accuracy and the modelling } \\
\text { procedure? (i.e. how close to the actual mixture composition are the } \\
\text { results derived using the three classification methods?) }\end{array}$
\end{tabular}


Only cluster 3 subsurface sources and all surface sources (this mixture was decided upon only after the use of the cluster analysis)

Only cluster 1 surface sources and all subsurface sources (this mixture was decided upon only after the use of the cluster analysis)

Only a random $10 \%$ of samples from each source group

All source samples with $10-30 \%$ of the sample mass added as organic matter (cotton wool)

All source samples sieved to $<38 \mu \mathrm{m}$

All source samples sieved to 63 $38 \mu \mathrm{m}$
These three alterations to the mixtures investigate how much error can be caused by regional variability in sediment source inputs with each source group classification method. For example, if only a small part of channel bank composed of an unusual tracer signature undergoes mass failure contributing a disproportionally large amount of sediment.

How does the classification of source groups affect the error resulting from the enrichment in sediment-associated organic matter during its erosion, transport and storage?

How does the classification of source groups affect the error that can result from particle size changes during sediment erosion, transport, deposition and delivery.

\subsection{Source group fingerprinting procedure}

The key theory behind this paper is that the cluster analysis source group classification method will reduce the within-source group variability and increase the inter-source group variability. To test if the classification methods achieve this aim, tracer variability ratios of the percentage difference in median tracer concentration between source groups divided by the mean within-source group variability (coefficient of variation; \%) were used (Pulley et al. 2015a). Prior to the identification of the composite fingerprints for tracing, any tracer with a maximum variability ratio lower than 1 in any pair of source groups was removed from further analysis to help reduce the uncertainty present in the final results.

A genetic algorithm driven linear discriminant analysis (GA-LDA; cf. Collins et al. 2012, $2013,2014)$ was then used to identify the composite fingerprint of tracers best able to discriminate between the sediment source groups. The GA-LDA was repeated for each of the three sediment source group classification methods, to produce a unique composite 
fingerprint for each. The percentage of source samples correctly classified into their respective group with the optimum fingerprint for each classification method was compared.

An unmixing model (Equation 1) was used to apportion the contributions of sediment in each of the artificial mixtures (Table 2). Before inclusion in the model, all tracers were rescaled to range between 0 and 1 by dividing each model value by the maximum value found in any source group. The unmixing model incorporated Monte Carlo uncertainty analysis (Rowan et al. 2000) which repeated the model for 3000 iterations, each iteration with a random tracer value from within the range of the median $+/$ - one median absolute deviation (MAD) of each source group. The model outputs were presented as the average median Monte Carlo result with $5^{\text {th }}$ and $95^{\text {th }}$ percentile uncertainty error bars. No correction factors for organic matter or particle size were used, and no weightings for within-source variability and discriminatory efficiency were applied, as these may introduce additional uncertainty into the fingerprinting process (Smith and Blake 2014; Laceby and Olley, 2014). The results of the modelling were compared to the known proportions of each source group present in the artificial mixtures. The mean absolute difference (cf. Collins et al., 1997) between the median Monte Carlo source estimations and the known proportions of each source was calculated for the 3 repetitions of each mixture (Table 2). Using this method, the error present when unmixing the uncorrupted and deliberately corrupted mixtures was quantified to find how source classification affects the accuracy of a hypothetical fingerprinting study.

\section{Equation 1. The structure of the sediment source unmixing model.}

$$
\sum_{i=1}^{n}\left\{\left(C_{i}-\left(\sum_{s=1}^{m} P_{s} S_{s i}\right)\right) / C_{i}\right\}^{2}
$$


Where $C_{i}=$ concentration of fingerprint property (i) in sediment sample; $P_{s}=$ the optimised percentage contribution from source category $(\mathrm{s}) ; \mathrm{S}_{\mathrm{si}}=$ median concentration of fingerprint property (i) in source category (s) $n=$ number of fingerprint properties comprising the optimum composite fingerprint; $\mathrm{m}=$ number of sediment source categories.

\section{Results and discussion}

\subsection{Source group classification}

The first classification scheme separated samples into simple surface and subsurface sources (two source groups used in most published studies). The second source group classification used the tracer signatures in a two-step cluster analysis. A total of 7 Principal Components were identified in the tracer signatures accounting for $82.3 \%$ of the variance in the total data set. The tracer most strongly correlated with each Principal Component was identified (and are those shown in Table 3) and included in the two-step cluster analysis. The cluster analysis identified that a 3 cluster solution was optimal. The results presented in Table 3 suggest that these clusters are based on catchment geology (Figure 1) with cluster 1 representing ironstone-derived topsoils and channel banks (rich in vanadium and iron), cluster 2 representing mudstone and diamicton (rich in lithium) and the third component representing limestone-derived channel bank material (rich in strontium and calcium). It is of note that limestone is not marked on the geology map (Figure 1) highlighting a potential shortcoming of a source classification schemes based only upon a geology or soil map as opposed to one which uses the tracer signatures for classification. Therefore, in the case of this study, the tracer signatures are likely to be more naturally defined according to local geology rather than as simple surface and subsurface sources. In other catchments this may be different, 
reflecting land use (Walling et al., 1993) or soil type. These groupings were used to form the artificial mixtures used for testing in this paper.

Table 3: The locations of cluster centres in the two-step cluster analysis (group classification method 2 only). The cluster with the highest value for each tracer is highlighted in bold (See Table 1 for a description of colour signatures).

\begin{tabular}{|c|c|c|c|}
\hline & \multicolumn{3}{|c|}{ Cluster } \\
\hline & 1 & 2 & 3 \\
\hline Interpretation & $\begin{array}{l}\text { Oordial Ironstone and } \\
\text { Sand and ironstone }\end{array}$ & $\begin{array}{l}\text { Mudstone } \\
\text { and } \\
\text { diamicton }\end{array}$ & Limestone \\
\hline $\begin{array}{l}\text { Percentage of total } \\
\text { samples }(78) \text { in group }\end{array}$ & 9.0 & 70.5 & 20.5 \\
\hline Green (intensity) & 90.67 & 107.05 & 127.94 \\
\hline $\operatorname{SIRM}\left(10^{-3} \mathrm{Am}^{3} \mathrm{~kg}^{-1}\right)$ & 9.65 & 2.06 & 0.91 \\
\hline $\operatorname{Sr}\left(\mathrm{mg} \mathrm{kg}^{-1}\right)$ & 58.48 & 36.65 & 109.2 \\
\hline $\mathrm{V}\left(\mathrm{mg} \mathrm{kg}^{-1}\right)$ & 114.75 & 50.31 & 61.28 \\
\hline $\mathbf{L i}\left(\mathrm{mg} \mathrm{kg}^{-1}\right)$ & 11.12 & 15.07 & 9.81 \\
\hline Mo $\left(\mathrm{mg} \mathrm{kg}^{-1}\right)$ & 0.75 & 0.56 & 0.55 \\
\hline
\end{tabular}

The third source group classification method used the three cluster groups as a starting point and split the surface and subsurface samples in each cluster group into their own separate groups. After doing this it was found that there was only one subsurface sample left in the ironstone subsurface cluster; as a result the subsurface ironstone source group was removed from further analysis. The source groups identified with scheme 3 can be seen in (Figure 2, 3)

The source groups derived using each classification scheme were mapped on a diagram representing the down bank profiles at each sampling point (Figure 2). The location of each sampling point in the study catchment is shown in Figure 1. Mapping the two-step cluster analysis source groups (classification scheme 2) shows that the majority of ironstone classified samples are located in the centre of the catchment and on the surface (Figure 2). The limestone group classified samples are all located in subsurface material at sampling 
sites 3, 4, 7 and 8 . In contrast, clay and diamicton derived material is present throughout the entire study area.

From the viewpoint of a catchment manager wanting to know where to target mitigation measures, classification scheme 2 , using only the cluster analysis, is perhaps the least useful since it could only identify how much sediment originated from some of the small outcrops of limestone and ironstone in the centre of the study catchment. The most useful classification scheme is number 3 with the greatest number of source groups.

Figure 2: A simplified map of the source samples derived using the different source group classification schemes; each diagram represents the down bank profile with samples over the $0 \mathrm{~m}$ line originating from adjacent agricultural fields and samples immediately below the line being topsoil overlying the channel bank. 


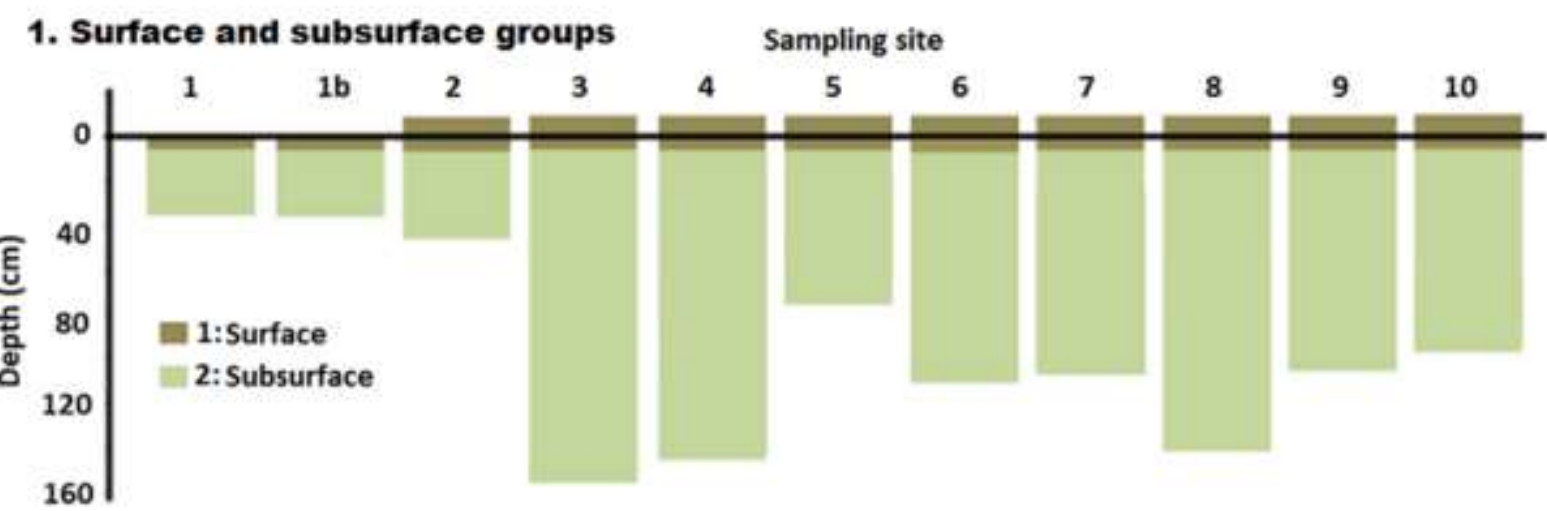

2. Cluster analysis derived source groups

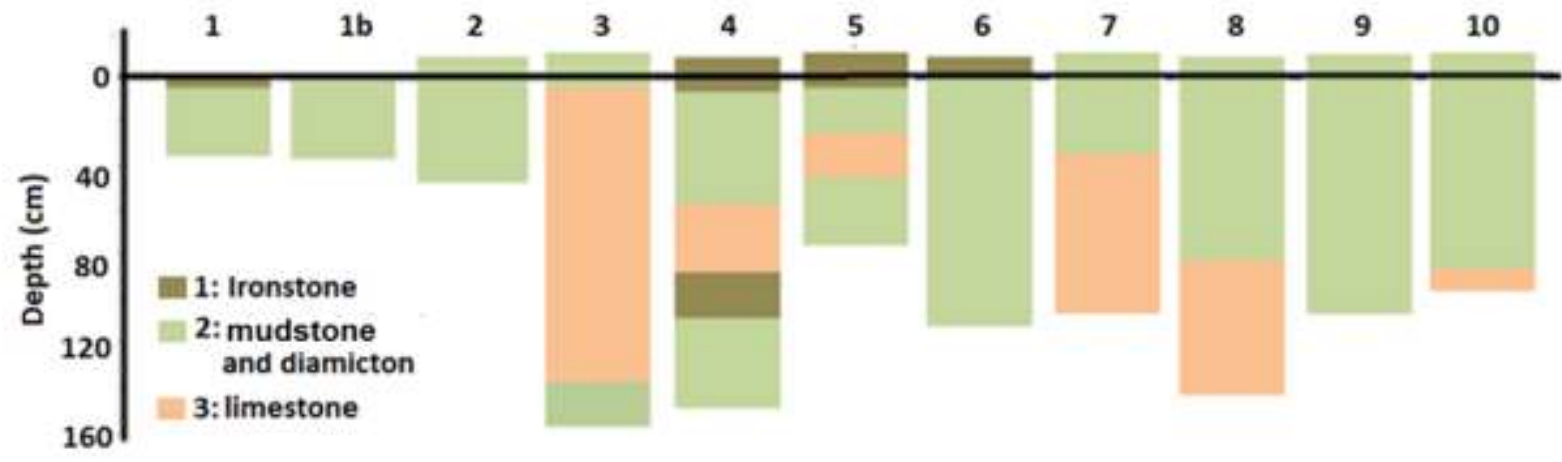

3. Cluster derived groups with the reclassification of clusters into surface and subsurface components

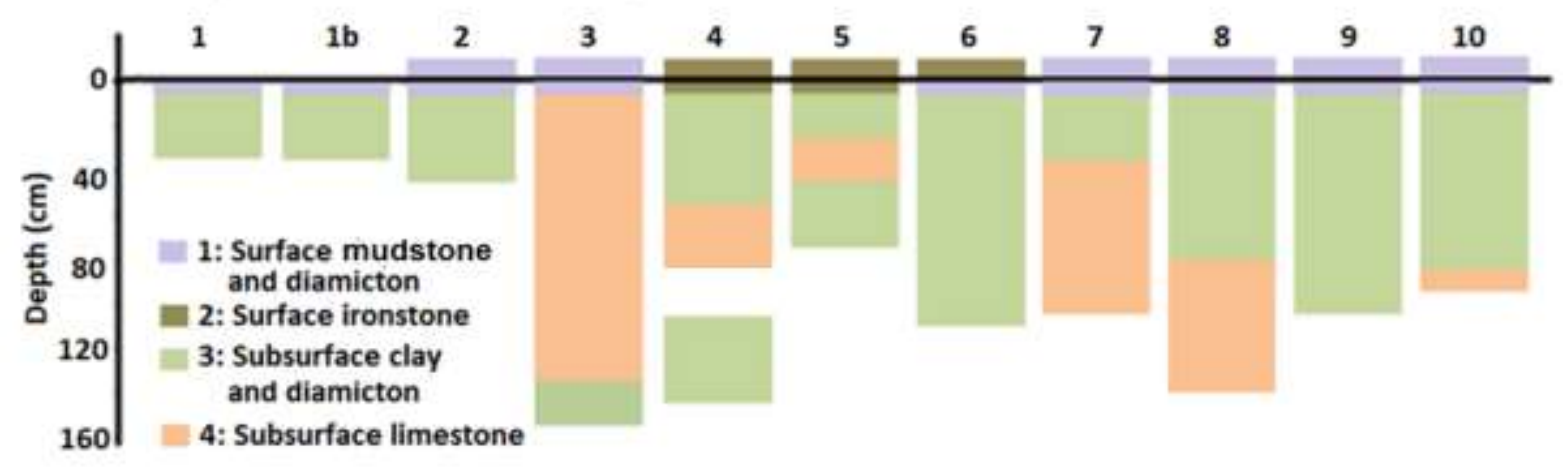

\subsection{Within- and between-source group variability}

This section compares the percentage difference in median tracer signatures between the source groups and within-source group variability (mean coefficient of variability as a \%) for the three source group classification schemes, using a tracer variability ratio (intra / inter group variability). 
The cluster analysis derived source groups (classification scheme 2) greatly increased (by up to $2122 \%$, median $194 \%$ ) the variability ratios over the simple surface and subsurface source groups (scheme 1), indicating a greater difference in tracer signatures between the source groups and lower within-source group variability (Table 4). The variability ratios remained substantially higher than the simple surface and subsurface source groupings (scheme 1) when the cluster analysis based groups were split into a surface and subsurface component (scheme 3). These results thereby indicate that the lowest uncertainty would be propagated through to the unmixing model outputs with classification schemes 2 and 3 compared to scheme 1.

Table 4: Source group median tracer concentrations, median absolute deviations (MAD) and tracer variability ratios for the different classification methods (the tracers shown are those selected in the PCA as representing $82.2 \%$ of variance in the total tracer dataset, not necessarily those used in the composite fingerprints).

\begin{tabular}{|c|c|c|c|c|c|c|c|c|c|}
\hline \multicolumn{10}{|c|}{ 1: Surface and subsurface source groups } \\
\hline Group & Name & & $\begin{array}{c}\text { Number } \\
\text { of } \\
\text { samples }\end{array}$ & SIRM & $\mathbf{L i}$ & Mo & $\mathbf{S r}$ & $\mathbf{V}$ & Green \\
\hline \multirow[t]{2}{*}{1} & Surface & Median & 20 & 3.05 & 13.39 & 0.56 & 39.81 & 55.84 & 99.8 \\
\hline & & MAD & & 0.87 & 2.96 & 0.13 & 13.45 & 14.19 & 3.2 \\
\hline \multirow[t]{2}{*}{2} & $\begin{array}{l}\text { Channel } \\
\text { banks }\end{array}$ & Median & 58 & 1.42 & 12.27 & 0.52 & 38.55 & 51.88 & 111.5 \\
\hline & & MAD & & 0.61 & 2.54 & 0.12 & 13.68 & 12.15 & 7.4 \\
\hline \multicolumn{2}{|c|}{$\begin{array}{c}\text { Surface and channel } \\
\text { banks }\end{array}$} & \multicolumn{2}{|c|}{ Variability Ratio } & 1.50 & 0.39 & 0.29 & 0.09 & 0.29 & 2.15 \\
\hline \multicolumn{10}{|c|}{ 2: Two - step cluster source groups } \\
\hline \multirow[t]{2}{*}{1} & Ironstone & Median & 7 & 10.20 & 11.89 & 0.79 & 51.50 & 113.20 & 94.6 \\
\hline & & MAD & & 5.69 & 3.22 & 0.20 & 5.90 & 41.65 & 3.3 \\
\hline \multirow[t]{2}{*}{2} & Clay & Median & 55 & 1.88 & 13.43 & 0.53 & 32.83 & 47.76 & 105.6 \\
\hline & & MAD & & 0.58 & 2.96 & 0.10 & 7.93 & 9.79 & 4.2 \\
\hline \multirow[t]{2}{*}{3} & $\begin{array}{l}\text { Limestone } \\
\text { subsurface }\end{array}$ & Median & 16 & 0.86 & 9.81 & 0.49 & 107.48 & 50.51 & 126.3 \\
\hline & & MAD & & 0.23 & 2.50 & 0.12 & 46.58 & 16.04 & 6.2 \\
\hline $\begin{array}{r}\text { Ironston } \\
+\end{array}$ & $\begin{array}{l}\text { nd mudstone } \\
\text { micton }\end{array}$ & Variabi & ity Ratio & 1.89 & 0.47 & 1.51 & 2.04 & 2.02 & 2.79 \\
\hline
\end{tabular}




\begin{tabular}{|c|c|c|c|c|c|c|c|}
\hline \multirow{2}{*}{$\begin{array}{l}\text { Ironstone and limestone } \\
\text { subsurface } \\
\text { Mudstone }+ \text { diamicton } \\
\text { and limestone } \\
\text { subsurface }\end{array}$} & Variability Ratio & 2.21 & 0.67 & 1.54 & 1.90 & 1.62 & 6.01 \\
\hline & Variability Ratio & 1.87 & 1.13 & 0.38 & 2.06 & 0.21 & 3.71 \\
\hline & Maximum ratio & 1.89 & 1.13 & 1.54 & 2.06 & 1.62 & 3.71 \\
\hline \multicolumn{8}{|c|}{ 3: Two - step cluster source with only clay surface sources reclassified } \\
\hline $\begin{array}{l}\text { Ironstone } \\
\text { surface }\end{array}$ & Median & 10.20 & 11.89 & 0.79 & 51.50 & 113.20 & 94.60 \\
\hline \multirow{3}{*}{ subsurface } & MAD & 5.69 & 3.22 & 0.20 & 5.90 & 41.65 & 3.30 \\
\hline & Median & 1.65 & 13.43 & 0.53 & 33.76 & 51.60 & 108.10 \\
\hline & MAD & 0.65 & 2.96 & 0.10 & 7.30 & 10.44 & 4.20 \\
\hline \multirow[t]{2}{*}{ subsurface } & Median & 0.86 & 9.81 & 0.49 & 107.48 & 50.51 & 126.30 \\
\hline & MAD & 0.23 & 2.50 & 0.12 & 46.58 & 16.04 & 6.15 \\
\hline \multirow[t]{2}{*}{ surface } & Median & 2.33 & 13.39 & 0.54 & 28.53 & 47.37 & 101.15 \\
\hline & MAD & 0.89 & 2.96 & 0.12 & 7.11 & 12.23 & 1.75 \\
\hline $\begin{array}{l}\text { Ironstone surface and } \\
\text { mudstone }+ \text { diamicton } \\
\text { subsurface }\end{array}$ & Variability Ratio & 1.76 & 0.47 & 1.51 & 2.08 & 1.91 & 3.39 \\
\hline $\begin{array}{l}\text { Ironstone surface and } \\
\text { limestone subsurface }\end{array}$ & Variability Ratio & 2.21 & 0.67 & 1.54 & 1.90 & 1.62 & 6.01 \\
\hline $\begin{array}{l}\text { Ironstone surface and } \\
\text { mudstone }+ \text { diamicton } \\
\text { surface }\end{array}$ & Variability Ratio & 1.64 & 0.46 & 1.35 & 2.45 & 1.86 & 2.48 \\
\hline $\begin{array}{l}\text { Mudstone + diamicton } \\
\text { subsurface and } \\
\text { limestone subsurface }\end{array}$ & Variability Ratio & 1.45 & 1.13 & 0.38 & 2.11 & 0.08 & 3.29 \\
\hline $\begin{array}{l}\text { Mudstone + diamicton } \\
\text { subsurface and clay } \\
\text { surface }\end{array}$ & Variability Ratio & 0.75 & 0.01 & 0.07 & 0.67 & 0.36 & 2.29 \\
\hline \multirow[t]{2}{*}{$\begin{array}{c}\text { Limestone subsurface } \\
\text { and mudstone }+ \\
\text { diamicton surface }\end{array}$} & Variability Ratio & 1.93 & 1.12 & 0.40 & 2.15 & 0.22 & 6.03 \\
\hline & Maximum ratio & 2.21 & 1.13 & 1.54 & 2.45 & 1.91 & 6.03 \\
\hline
\end{tabular}

\subsection{Discriminant analysis}

The GA-LDA produced composite fingerprints able to classify $100 \%$ of the source samples into their correct groups for all of the source group classification schemes. On this basis, all three classification schemes are suitable for achieving basic discrimination using the available tracers. The cluster analysis grouping method (scheme 2) required fewer tracers to achieve this discrimination than the other groups. Recent research by Sheriff et al. (2015) has 
suggested that larger composite fingerprints may reduce uncertainty in some fingerprinting methodologies. It was, however, found that including additional tracers to increase the size of the fingerprint for source classification scheme 2 did not result in a significant change to unmixing model accuracy in this study, and for this reason, the results derived using the original smaller number of signatures are presented.

Table 5: The optimum composite fingerprint selected for each source group classification scheme.

\begin{tabular}{|c|c|c|}
\hline & $\begin{array}{l}\text { Discriminatory } \\
\text { power }\end{array}$ & Tracers selected \\
\hline 1: Original groups & $100 \%$ & SIRM, Red, Green, HRGB, IRGB, Al, K, Li, Mn, P, Sr, V, Zn \\
\hline $\begin{array}{l}\text { 2: Cluster analysis } \\
\text { groups }\end{array}$ & $100 \%$ & SIRM, IRGB, Fe, P, Sr \\
\hline $\begin{array}{l}\text { 3: Cluster groups } \\
\text { with separate surface } \\
\text { and subsurface } \\
\text { components }\end{array}$ & $100 \%$ & $\begin{array}{l}\chi \text { lf, } \chi \text { am, Red, Green, Blue, HRGB, Colouration Index, Ba, Fe, } \\
\text { Li, Mg, Sr }\end{array}$ \\
\hline
\end{tabular}

\subsection{Unmixing model outputs}

The artificial mixtures of known proportions of source samples (Table 2) were run through the unmixing model (Equation 1) using the composite fingerprints in Table 5, to assess how the different source classification schemes affected the accuracy of the source apportionment modelling results. Six of the seven mixtures were deliberately corrupted by sieving adding organic matter or using only a small number of samples from each source group (Table 2). This was done to mimic some of the key possible sources of tracer non-conservatism in the natural environment.

Figure 3 shows some examples of the actual and modelled proportions of sediment from each source group in the artificial mixtures derived for the different source group classification 
schemes. By way of summary, the results are only presented for one of the three samples unmixed and four of the seven mixture types. The full set of graphs are provided in the online supplementary material and the results are summarised in Table 6.

The error bars representing the $5^{\text {th }}$ to $95^{\text {th }}$ percentile range of uncertainty in model results were very large with the simple surface and subsurface source groups (mean for all samples analysed $71.31 \%$ on the $0-100 \%$ contribution scale, standard deviation $18.19 \%$ ) (scheme 1 ). The range of uncertainty was smallest with the cluster groups (mean $31.05 \%$, standard deviation $12.90 \%$ ) (scheme 2) and cluster groups split into surface and subsurface components (mean 38.63\%, standard deviation 19.93\%) (scheme 3).

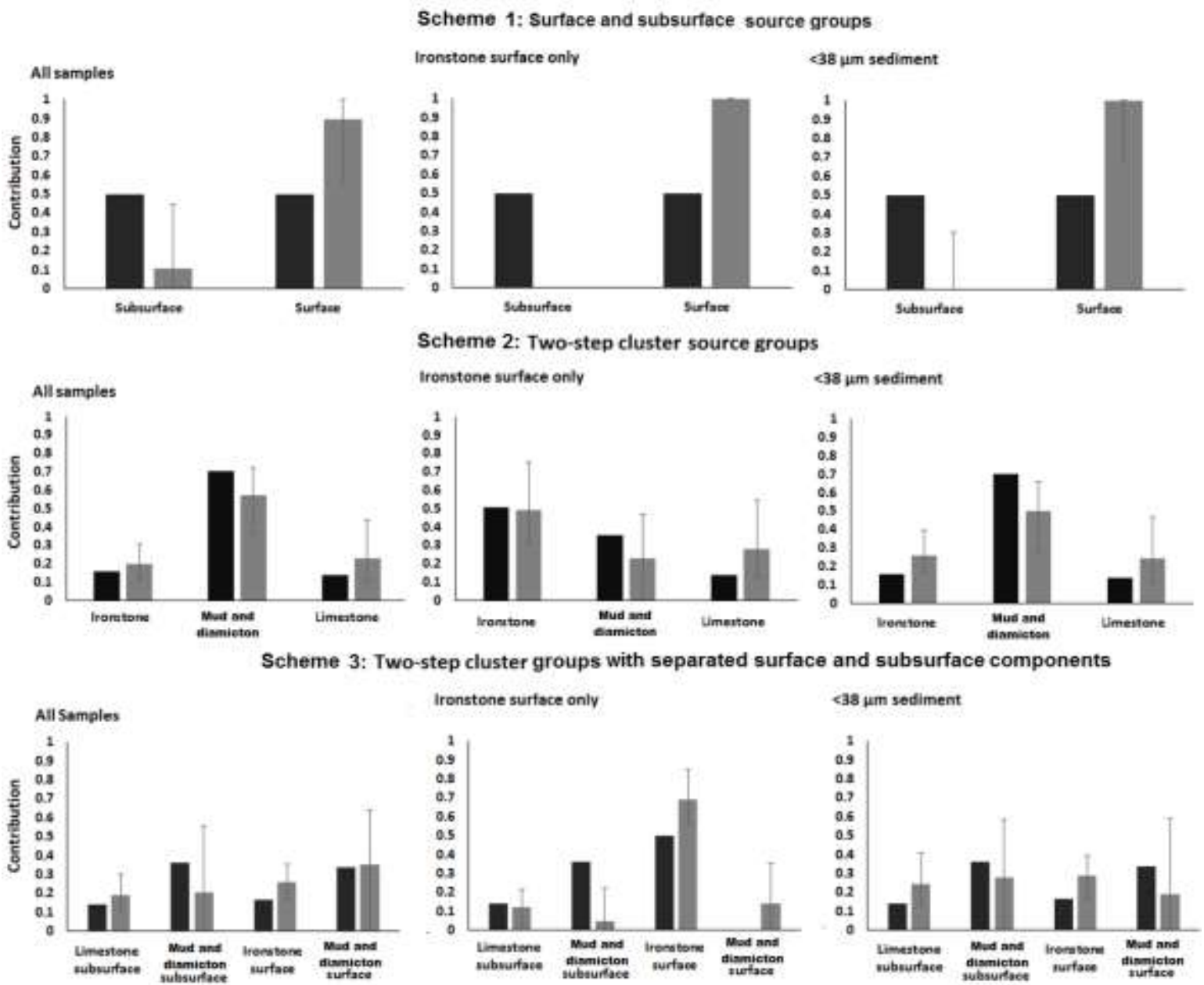

Figure 3: The actual (black) and modelled (grey) median proportion of sediment in one of the three artificial mixtures, fingerprinted using the different source grouping 


\section{methods, with $5^{\text {th }}$ and $95^{\text {th }}$ percentile uncertainty bars. The latter represent feasible unmixing model solutions.}

Table 6 summarises the mean differences between the actual and modelled contributions of each source to the sediment mixtures for every unmixing model run. The outputs of nearly every model run were statistically significantly different $(\mathrm{P}<0.05)$ to those of other models. For example, the source apportionment results of the mixtures with organic matter added were significantly different to those without organic matter added. The simple surface and subsurface source groupings (scheme 1) resulted in large errors (mean 15.8\%), even when no alterations are made to the mixtures, but the actual composition of the mixtures did, however, mostly fall within the large range of model uncertainty when the mixtures were unaltered (Table 6; Figure 3). The mean percentage differences between median tracer concentrations in the source groups for the composite fingerprints used were $16.75 \%$ (scheme 1), $42.11 \%$ (scheme 2) and 34.71\% (scheme 3) (Table 4). The small difference in tracer signatures between source groups using scheme 1 explains its poor performance, as the errors associated with laboratory tracer measurement were quantified as between $4.1 \%$ and $11.6 \%$, which could remove much of the discrimination provided by the tracers used. Schemes 2 and 3 produce far lower errors with the unaltered mixtures (Mean 7.7 and 10.1\%).

Using only part of each source group (either $10 \%$ of source samples or a samples only from specific cluster group in Table 3 ) in the mixtures to replicate sediment delivery from only a small part of the study catchment resulted in large errors in provenance apportionment when source group classification scheme 1 was used (mean 21.7\%). Classification schemes 2 and 3 had much lower errors (mean $12.9 \%$ ). Therefore, where sediment delivery to a river is highly localised, significant errors could be introduced if source groups are classified on the basis of 
catchment-wide generic subsurface / surface sources alone in a catchment with a heterogeneous geology or soil type when a composite fingerprinting approach is used.

Sieving the artificial mixtures to $<38 \mu \mathrm{m}$ and $63-38 \mu \mathrm{m}$ to replicate changes to fine sediment particle size during its transportation from source to river channel resulted in large errors (mean 28.6\%) when scheme 1 was used and lower errors (mean 13\%) when classification schemes 2 and 3 were used. The largest error resulting from any deliberate corruption to the artificial source mixtures was caused when the samples were sieved to 63 $38 \mu \mathrm{m}$ (mean 23.8\%). This large error possibly suggests that the basis for source discrimination may be significantly different between the $<38 \mu \mathrm{m}$ and $63-38 \mu \mathrm{m}$ fractions of the source samples. Previous research has reported such a finding. For example, Motha et al. (2003) and Pye et al. (2007) found higher concentrations of many tracers in fine, $<20 \mu \mathrm{m}$, fractions of catchment source material. Alternatively, Horowitz and Elrick (1987) found anthropogenic pollutants such as Zn concentrated in coarser silts of stream sediments.

When cotton wool was added to the artificial mixtures to replicate the enrichment of organic matter during sediment transport, this alteration counterintuitively slightly improved model accuracy (by a mean of $1.5 \%$ ). It may be that the sediment coated the organic matter meaning that the sediment colour was not significantly changed by the organic addition. Alternatively, it is possible that measurement error (of up to $11.6 \%$ ) caused the tracer concentrations measured in the mixtures to be too high. In this case dilution of the tracer signatures by organic matter may well result in the observed improvement.

Table 6: Mean absolute differences $(\%)$ between the actual and modelled proportions of each sediment source in the artificial mixtures using the different sediment source classification schemes. The lowest difference for each mixture is highlighted in bold. 


\begin{tabular}{|c|c|c|c|c|}
\hline & $\begin{array}{c}1 \\
\text { Surface and } \\
\text { subsurface } \\
\text { source groups }\end{array}$ & $\begin{array}{c}2 \\
\text { Two-step } \\
\text { cluster } \\
\text { groups }\end{array}$ & $\begin{array}{c}3 \\
\text { Two-step cluster } \\
\text { groups with separate } \\
\text { surface and subsurface } \\
\text { components } \\
\end{array}$ & Mean \\
\hline No alteration & 15.8 & $10.1^{\mathrm{n} / \mathrm{a}}$ & $7.7^{+}$ & 11.2 \\
\hline $\begin{array}{l}\text { Cluster } 3 \text { channel } \\
\text { banks samples } \\
\text { only }\end{array}$ & $16.1^{*}$ & $12.1^{*}$ & $12.3^{*}$ & 13.5 \\
\hline $\begin{array}{l}\text { Random } 10 \% \text { of } \\
\text { each source } \\
\text { group }\end{array}$ & $26.8^{*}$ & $\mathrm{n} / \mathrm{a}$ & $15.5^{*}$ & 21.2 \\
\hline $\begin{array}{l}\text { Cluster } 1 \text { surface } \\
\text { samples only }\end{array}$ & $22.3^{*}$ & $11.1^{*}$ & $13.7^{*}$ & 15.7 \\
\hline $\begin{array}{l}10-30 \% \text { organic } \\
\text { matter added }\end{array}$ & 14.8 & $9.0^{*}$ & 5.4 & 9.7 \\
\hline $\begin{array}{l}\text { Mixtures sieved } \\
\text { to } 63-38 \mu \mathrm{m}\end{array}$ & $36.6^{*}$ & $15.6^{*}$ & $19.3^{*}$ & 23.8 \\
\hline $\begin{array}{l}\text { Mixtures sieved } \\
\text { to }<38 \mu \mathrm{m}\end{array}$ & 20.6 & $15.7^{*}$ & $12.7^{*}$ & 16.3 \\
\hline Mean & 21.8 & 12.3 & 12.4 & \\
\hline
\end{tabular}

+ Significantly different model output distribution to the simple surface and subsurface classifications (for contributions from surface sources), Kruskal Wallis test $\mathrm{P}<0.05$.

* Significantly different distribution to the unaltered mixture, Kruskal Wallis test $\mathrm{P}<0.05$.

\section{Conclusions}

The findings of this paper demonstrate how small differences in tracer signatures between sediment source groups and a high within-source variability can introduce significant uncertainty into unmixing model results. As a result, it was found that the simple classification of catchment sources as generic surface and subsurface sources in a catchment with a heterogeneous geology resulted in large amount of error when using a composite fingerprinting approach. This error was significantly reduced by the cluster analysis based method, and was not significantly increased by splitting the cluster analysis source groups into surface and subsurface components to suit catchment management goals. Therefore, a 
cluster analysis based classification method with the modification of cluster groups appears to be the optimum method within the Sywell Reservoir catchment. This is likely to be the case for many other river catchments.

The effects of tracer non-conservatism were found to be substantially reduced by the high tracer variability ratio associated with the cluster analysis based classification methods. The reasoning behind this is that the source group signal of the tracers (inter-group variability) is larger than the noise of tracer non-conservatism with these methods. An additional advantage to the cluster analysis based methods is that far smaller errors are introduced by highly localised sediment inputs from only a small part of the catchment, which may have highly distinctive tracer concentrations (e.g. from the ironstone geology in the case of the Sywell study catchment).

Whilst this paper found that the sediment source groups in the cluster analysis were strongly controlled by catchment geology it should be emphasised that this method is likely applicable to catchments with homogenous soil types, channel bank composition and anthropogenic tracer inputs. As a result, we would recommend consideration of objective source classification schemes in combination with the modification of source groups to suit management goals. On the basis of our findings here, the optimum classification scheme for applying sediment source fingerprinting in the Sywell catchment is presented in Figure 4). 
Figure 4: A flow diagram of the optimum source classification scheme identified for the Sywell reservoir catchment.

\section{Acknowledgements}

The work on this project was funded through a postdoctoral scholarship (to Simon Pulley) provided by Rhodes University. The equipment used for the analysis of samples was provided by the University of Northampton. We would also like to thank the two anonymous reviewers and editor for their helpful suggestions which have greatly improved this work.

\section{References}


Anderson, N.J., Rippey. B., 1988. Diagenesis of magnetic minerals in the recent sediments of a eutrophic lake. Limnol. Oceanogr. 33, 1476-1492. DOI: 10.4319/1o.1988.33.6_part_2.1476

Barron, V., Torrent, J., 1986. Use of the Kubelka-Munk theory to study the influence of iron oxides on soil colour. Eur. J. Soil Sci. 37, 499- 510. DOI: 10.1111/j.1365-

2389.1986.tb00382.x

British Geological Survey., 2011. DiGMap GB-50 Bedrock and Superficial deposits, British Geological Survey, Nottingham, UK.

Carr, A.S., Boom, A., Chase, B.M,, Roberts, D.L., Roberts, Z.E., 2010. Molecular fingerprinting of wetland organic matter using pyrolysis-GC/MS: an example from the southern Cape coastline of South Africa. J. Paleolim. 44, 947-961. DOI: 10.1007/s10933010-9466-9

Collins, A.L., Walling, D.E., 2002. Selecting fingerprint properties for discriminating potential suspended sediment sources in river basins. J. Hydrol. 261, 218-244. DOI:10.1016/S00221694(02)00011-2

Collins, A.L., Walling, D.E., 2007. Sources of fine sediment recovered from the channel bed of lowland groundwater-fed catchments in the UK. Geomorphology. 88, $120-138$.

Collins, A.L., Walling, D.E. Leeks, G.J.L., 1998. Use of composite fingerprints to determine the spatial provenance of the contemporary suspended sediment load transported by rivers. Earth. Surf. Proc. Land 23, 31-52. DOI: 10.1002/(SICI)1096-9837(199801)23:1<31::AIDESP816>3.0.CO;2-Z 
Collins, A.L., Walling, D.E., Sichingabula, H.M., Leeks, G.J.L., 2001. Suspended sediment source fingerprinting in a small tropical catchment and some management implications. Appl. Geogr. 21(4), 387-412.

Collins, A.L., Walling, D.E., Stroud, R.W., Robson, M., Peet, L.M., 2010a. Assessing damaged road verges as a suspended sediment source in the Hampshire Avon catchment, southern United Kingdom. Hydrol. Process. 24, 1106-1122. DOI: 10.1002/hyp.7573

Collins, A.L., Williams, L.J., Zhang, Y.S., Marius, M., Dungait, J.A.J., Smallman, D.J., Dixon, E.R., Stringfellow, A., Sear, D.A., Jones, J.I., Naden, P.S., 2014. Sources of sediment-bound organic matter infiltrating spawning gravels during the incubation and emergence life stages of salmonids. Agric. Ecosyst. Environ. 196, 76-93. DOI: 10.1016/j.agee.2014.06.018

Collins, A.L., Zhang, Y.S., Hickinbotham, R., Bailey, G., Darlington, S., Grenfell, S. E., Evans, R., Blackwell, M., 2013. Contemporary fine-grained bed sediment sources across the River Wensum Demonstration Test Catchment, UK. Hydrol. Process. 27, 857-884. DOI: 10.1002/hyp.9654

Collins, A.L., Zhang, Y., McChesney, D., Walling, D.E., Haley, S.M., Smith, P., 2012. Sediment source tracing in a lowland agricultural catchment in southern England using a modified procedure combining statistical analysis and numerical modelling. Sci. Total Environ. 414, 301-317. DOI: 10.1016/j.scitotenv.2011.10.062

Collins, A.L., Zhang, Y., Walling, D.E., Grenfell, S.E., Smith, P., 2010b. Tracing sediment loss from eroding farm tracks using a geochemical fingerprinting procedure combining local and genetic algorithm optimisation. Sci. Total Environ. 408, 5461-5471. DOI: 10.1016/j.scitotenv.2010.07.066 
Devereux, O.H., Prestegaard, K.L., Needelman, B.A., Gellis, A.C., 2010. Suspendedsediment sources in an urban watershed, Northeast Branch Anacostia River, Maryland: Hydrol. Process. 24(11), 1391-1403.

D’Haen, K., Verstraeten, G., Degryse, P., 2012. Fingerprinting historical fluvial sediment fluxes. Prog. Phys. Geog. 362, 154-186. DOI: 10.1177/0309133311432581

Evrard, O., Poulenard, J., Némery, J., Ayrault, S., Gratiot, N., Duvert, C., Prat, C., Lefèvre, I., Bonté, P., Esteves, M. 2013. Tracing Sediment sources in a tropical highland catchment of central Mexico by using conventional and alternative fingerprinting methods. Hydrol. Process. 27(6), 911-922.

Gellis, A.C., Hupp, C.R., Pavich, M.J., Landwehr, J.M., Banks, W.S.L., Hubbard, B.E., Langland, M.J., Ritchie, J.C., Reuter J.M. 2009. Sources, transport, and storage of sediment in the Chesapeake Bay Watershed. U.S. Geological Survey Scientific Investigations Report 2008-5186: 95.

Guieu, C., Loÿe-Pilot, M.-D., Benyahya, L., Dufour, A. 2010. Spatial variability of atmospheric fluxes of metals ( $\mathrm{Al}, \mathrm{Fe}, \mathrm{Cd}, \mathrm{Zn}$ and $\mathrm{Pb}$ ) and phosphorus over the whole Mediterranean from a one-year monitoring experiment: Biogeochemical implications. Marine Chemistry. 120, 164-178.

Haddadchi et al. (2013). Sediment fingerprinting in fluvial systems: Review of tracers, sediment sources and mixing models. Int. J. Sediment Res. 28(4). 560-578.

Haddadchi, A., Olley, J., Laceby, P., 2014. Accuracy of mixing models in predicting sediment source contributions. Sci. Total Environ. 497-498, 139-152. DOI: 10.1016/j.scitotenv.2014.07.105. 
Horowitz, A.J., Elrick, K.A., 1987. The relation of stream sediment surface area, grain size and composition to trace element chemistry. Appl. Geochem. 2, 437-451. DOI: $10.1016 / 0883-2927(87) 90027-8$

Horowitz, A.J., Stephens, V.C., 2008. The effects of land use on fluvial sediment chemistry for the conterminous U.S. - results from the first cycle of the NAWQA Program: trace and major elements, phosphorus, carbon, and sulfur. Sci. Total Environ. 400, 290-314. DOI: 10.1016/j.scitotenv.2008.04.027

Klages, M.G., Hsieh, Y.P., 1975. Suspended Solids Carried by the Gallatin River of Southwestern Montana: II. Using Mineralogy for Inferring Sources. J. Environ. Quality. 4, 68-73.

Koiter, A.J., Owens, P.N., Petticrew, E.L., Lobb, D.A., 2013. The behavioural characteristics of sediment properties and their implications for sediment fingerprinting as an approach for identifying sediment sources in river basins. Earth-Sci. Rev. 125, 24-42. DOI: 10.1016/j.earscirev.2013.05.009

Koiter, A.J., Owens, P.N., Petticrew, E.L., Lobb, D.A., 2015. The role of gravel channel beds on the particle size and organic matter selectivity of transported fine-grained sediment: implications for sediment fingerprinting and biogeochemical flux research. J. Soils Sediments 15(10), 2174-2188. DOI: 10.1007/s11368-015-1203-6

Laceby, J.P., Olley, J., 2014. An examination of geochemical modelling approaches to tracing sediment sources incorporating distribution mixing and elemental correlations. Hydrol. Process. 29(6), 1669-1685. DOI: 10.1002/hyp.10287 
Laceby, J.P., Olley, J., 2015. An examination of geochemical modelling approaches to tracing sediment sources incorporating distribution mixing and elemental correlations. Hydrol. Process. 29, 1669-1685. DOI: 10.1002/hyp.10287

Lees, J.A., 1999. Evaluating magnetic parameters for use in source identification, classification and modelling of natural and environmental materials. In: Walden, J., Oldfield, F., Smith, J., (Eds.), Environmental magnetism, a practical guide. Technical Guide No. 6, Quaternary Research Association., London, pp. 113-138

Mabit, L., Benmansour, M., Walling, D.E., 2008. Comparative advantages and limitations of the fallout radionuclides $137 \mathrm{Cs}, 210 \mathrm{Pbex}$ and $7 \mathrm{Be}$ for assessing soil erosion and sedimentation J. Environ. Radioactiv. 99, 1799-1807

Maher, B.A., 1988. Magnetic properties of some synthetic submicron magnetites. Geophys. J. Roy. Astron. Soc. 94, 83-96. DOI: 10.1111/j.1365-246X.1988.tb03429.x

Martinez-Carrera, N., Gallart, F., Iffly, J.F., Pfister, L., Walling, D.E., Krein, A., 2008. Uncertainty assessment in sediment fingerprinting based on tracer mixing models: a case study from Luxembourg. IAHS Publ. No. 325.

McLaren, PA., 1981. Interpretation of trends in grain-size measurements. J. Sediment. Petrol. 51, 611-624.

Morton, R.D., Rowland, C., Wood, C., Meek, L., Marston, C., Smith, G., Wadsworth, R., Simpson, I., 2011. Land cover map 2007 (Vector, GB). NERC Environ. Inf. Data Centre.

Motha, J.A., Wallbrink, P.J., Hairsine, P.B. Grayson, R.B., 2002. Tracer properties of eroded sediment and source material. Hydrol. Process. 16, 1983-2000. DOI: 10.1002/hyp.397 
Motha, J.A., Wallbrink, P.J., Hairsine, P.B., Grayson, R.B., 2003. Determining the sources of suspended sediment in a forested catchment in south eastern Australia. Water Resour. Res.39, 1056. DOI: $10.1029 / 2001 \mathrm{WR} 000794$

Nadeu, E., Vente, J., Martínez-Mena, M., Boix-Fayos, C., 2011. Exploring particle size distribution and organic carbon pools mobilized by different erosion processes at the catchment scale. J. Soils Sediments. 11, 667-678. DOI: 10.1007/s11368-011-0348-1

Nosrati, K., Govers, G., Semmens, B.X., Ward, E.J., 2014. A mixing model to incorporate uncertainty in sediment fingerprinting. Geoderma. 217, 173-180.

Owens, P.N., Walling, D.E., Leeks, G.J.L., 1999. Use of floodplain sediment cores to investigate recent historical changes in overbank sedimentation rates and sediment sources in the catchment of the River Ouse, Yorkshire, UK. Catena. 36, 21-47. DOI: 10.1016/S03418162(99)00010-7

Palazón, L., Gaspar, L., Latorre, B., Blake, W.H., Navas, A., 2015. Identifying sediment sources by applying a fingerprinting mixing model in a Pyrenean drainage catchment. J. Soils Sediments. 15(10), 2067-2085.

Pulley, S., Foster. I., Rowntree, K., 2015c. Conservatism of mineral magnetic signatures in farm dam sediments in the South African Karoo; the potential effects of particle size and post depositional diagenesis. J. Soils Sediments. 15(12), 2387-2397. DOI: 10.1007/s11368-015$1265-5$

Pulley, S., Rowntree, K., 2016. The use of an ordinary colour scanner to fingerprint sediment sources in the South African Karoo. J. Environ. Manage. 165, 253-262. DOI: 10.1016/j.jenvman.2015.09.037 
Pulley, S.J., Foster, I., Antunes, P., 2015a. The uncertainties associated with sediment fingerprinting suspended and recently deposited fluvial sediment in the Nene river basin. Geomorphology. 228, 303-319. DOI: 10.1016/j.geomorph.2014.09.016

Pulley, S.J., Foster, I., Antunes, P., 2015b. The application of sediment fingerprinting to floodplain and lake sediment cores: assumptions and uncertainties evaluated through case studies in the Nene Basin, UK. J. Soils Sediments. 15(10), 2132-2154. DOI: 10.1007/s11368$015-1136-0$

Pye, K., Blott, S.J., Croft, D.J., Witton, S.J., 2007. Discrimination between sediment and soil samples for forensic purposes using elemental data: An investigation of particle size effects. Forensic Science International. 167(1), 30-42. DOI:10.1016/j.forsciint.2006.06.005

Ray, S.S., Singh, J.P., Das, G., Panigrahy, S., 2004. Use of high resolution remote sensing data for generating site-specific soil management plan. XX ISPRS congress, Comission 7 , Istanbul, Turkey. The international archives of the photogrammetry, remote sensing and spatial information sciences 127.

Roberts, A.P., Turner, G.M., 1993. Diagenetic formation of ferrimagnetic iron sulphide minerals in rapidly deposited marine sediments, South Island, New Zealand. Earth Planet. Sci. Lett. 115(1-4), 257-273. DOI: 10.1016/0012-821X(93)90226-Y

Rowan, J.S., Goodwill, P., Franks, S.W., 2000. Uncertainty estimation in fingerprinting suspended sediment sources. In: Foster, I.D.L., (Ed.) Tracers in Geomorphology. Wiley., Chichester: pp. 279-290.

Sheriff, S.P., Franks, S.W., Rowan, J.S., Ó hUallacháin, D., 2015. Uncertainty-based assessment of tracer selection, tracer non-conservativeness and multiple solutions in sediment 
fingerprinting using synthetic and field data. J. Soils Sediments. 15(10), 2101-2116. DOI.10.1007/s11368-015-1123-5

Slattery, M.C., Burt, T.P., 1997. Particle size characteristics of suspended sediment in hillslope runoff and stream flow. Earth Surf. Process. Landforms. 22, 705 - 719. DOI: 10.1002/(SICI)1096-9837(199708)22:8<705::AID-ESP739>3.0.CO;2-6

Slattery, M.C., Burt, T.P., Walden, J., 1995. The application of mineral magnetic measurements to quantify within-storm variations in suspended sediment sources. In: Leibundgut, C.H., (Ed.), Tracer Technologies for Hydrological Systems. IAHS Publ. No. 229, IAHS Press., Wallingford, pp. 143-151

Small, I.F., Rowan J.S., Franks, S.W., 2002. Quantitative sediment fingerprinting using a Bayesian uncertainty estimation framework. In: Dyer, F.J., Thoms, M.C., Olley, J,M,. (eds) Structure, Function and Management Implications of Fluvial Sedimentary Systems. IAHS Publication 276. Wallingford: IAHS, 443-450.

Small, I.F., Rowan, J.S., Franks, S.W., Wyatt, A., Duck, R.W., 2004. Bayesian sediment fingerprinting provides a robust tool for environmental forensic geoscience application. In: Pye, K., Croft, D.J. (eds) Forensic geoscience: principles, techniques and applications, vol 232. Geological Society, London, Special Publications, pp 207-213.

Smith, H.G., Blake, W.H., 2014. Sediment fingerprinting in agricultural catchments: A critical re-examination of source discrimination and data corrections. Geomorphology. 204, 177-191. DOI:10.1016/j.geomorph.2013.08.003

Stanton, R.K., Murray, A.S., Olley, J.M., 1992. Tracing the source of recent sediment using environmental magnetism and radionuclides in the karst of the Jenolan Caves, Australia. 
Erosion and Sediment Transport Monitoring Programmes in River Basins (Proceedings of the Oslo Symposium, August 1992). IAHS Publ. no.210. IAHS.

van der Waal, B., Rowntree, K., Pulley, S., 2015. Flood bench chronology and sediment source tracing in the upper Thina catchment, South Africa: the role of transformed landscape connectivity. J. Soils Sediments. 15(12), 2398-2411. DOI: 10.1007/s11368-015-1185-4

Viscarra Rossel, R.A., Minasny, B., Roudier, P., McBratney, A.B., 2006. Colour space models for soil science. Geoderma.133, 320-337. DOI: 10.1016/j.geoderma.2005.07.017

Walden, J., 1999. Remanence measurements. In: Walden J, Oldfield F, Smith JP. Editors. Environmental magnetism a practical guide, technical guide no 6. Quaternary Research Association., London. pp. 63-88.

Walden, J., Slattery, M.C., Burt, T.P., 1997. Use of mineral magnetic measurements to fingerprint suspended sediment sources: approaches and techniques for data analysis. J. Hydrol. 202(1-4), 353-372. DOI: 10.1016/S0022-1694(97)00078-4

Walling, D.E., 2004. Using environmental radionuclides to trace sediment mobilisation and delivery in river basins as an aid to catchment management. In: Proceedings of the Ninth International Symposium on River Sedimentation. Yichang, China. pp. 121-135.

Walling, D.E., 2007. Using environmental radionuclides as tracers in sediment budget investigations. Geomorphology. 88, $120-138$.

Walling, D.E., Collins, A.L., 2000. Integrated Assessment of Catchment Suspended Sediment Budgets: A Technical Manual. University of Exeter., Exeter. pp. 168. 
Walling, D.E., Owens, P.N., Leeks, G.J.L., 1999. Fingerprinting suspended sediment sources in the catchment of the River Ouse, Yorkshire, UK. Hydrol. Process. 13, 955-975. DOI: 10.1002/(SICI)1099-1085(199905)13:7<955::AID-HYP784>3.0.CO;2-G

Walling, D.E., Woodward J.C., 1995. Tracing sources of suspended sediment in river basins: a case study of the River Culm, Devon, UK. Mar. Freshwater Res. 46, 327-336.

Walling, D.E., Woodward, J.C., 1992. Use of radiometric fingerprints to derive information on suspended sediment sources. In: Bogen, J., Walling, D.E., Day, T.J., (Eds.). Erosion and Sediment Transport Monitoring Programmes in River Basins. Oslo: IAHS Publ. no. 210. pp. 153-164.

Wang, G., Oldfield, F., Xia, D., Chen, F., Liu, X., Zhang, W., 2012. Magnetic properties and correlation with heavy metals in urban street dust: A case study from the city of Lanzhou, China. Atmos. Environ. 46, 289-298. DOI: 10.1016/j.atmosenv.2011.09.059

Wang, Z., Govers, G., Steegen, A., Clymans, W, Van den Putte, A., Langhans, C., Merckx, R., Van Oost, K., 2010. Catchment-scale carbon redistribution and delivery by water erosion in an intensively cultivated area. Geomorphology. 124, 65-74. DOI :10.1016/j.geomorph.2010.08.010

Wilkinson, S.N. Hancock, G.J. Bartley, R. Hawdon, A.A. Keen, R.J., 2013. Using sediment tracing to assess processes and spatial patterns of erosion in grazed rangelands, Burdekin River basin, Australia. Agric. Ecosyst. Environ. 180, 90-102.

Yang, T., Liu, Q., Li, H., Zeng, Q., Chan, L., 2010. Anthropogenic magnetic particles and heavy metals in the road dust: Magnetic identification and its implications. Atmos. Environ. 44(9), 1175-1185. DOI:10.1016/j.atmosenv.2009.12.028 


\section{Online supplementary data}

Table S1: Loadings of the 7 largest principal components in the PCA analysis of tracer concentrations in the source samples.

\begin{tabular}{|c|c|c|c|c|c|c|c|}
\hline Component & \multicolumn{3}{|c|}{ Initial Eigenvalues } & \multicolumn{3}{|c|}{ Extraction Sums of Squared Loadings } & $\begin{array}{c}\text { Rotation } \\
\text { Sums of } \\
\text { Squared } \\
\text { Loadings } \\
\\
\text { Total } \\
\end{array}$ \\
\hline 1 & 10.990 & 26.805 & 26.805 & 10.990 & 26.805 & 26.805 & 7.978 \\
\hline 2 & 7.610 & 18.560 & 45.365 & 7.610 & 18.560 & 45.365 & 4.776 \\
\hline 3 & 5.228 & 12.751 & 58.117 & 5.228 & 12.751 & 58.117 & 6.534 \\
\hline 4 & 3.676 & 8.967 & 67.083 & 3.676 & 8.967 & 67.083 & 5.886 \\
\hline 5 & 2.794 & 6.814 & 73.898 & 2.794 & 6.814 & 73.898 & 7.662 \\
\hline 6 & 2.031 & 4.954 & 78.852 & 2.031 & 4.954 & 78.852 & 2.915 \\
\hline 7 & 1.402 & 3.419 & 82.271 & 1.402 & 3.419 & 82.271 & 5.286 \\
\hline
\end{tabular}

Table S2. The PCA structure matrix of tracer signatures in the source samples values larger than 0.4 and smaller than $\mathbf{- 0 . 4}$ are highlighted.

\begin{tabular}{cccccccc}
\hline \multicolumn{7}{c}{ Structure Matrix } \\
& \multicolumn{7}{c}{ Component } \\
\cline { 2 - 8 } Green & 1 & 2 & 3 & 4 & 5 & 6 & 7 \\
IRGB & -.970 & -.122 & -.056 & .079 & -.444 & .234 & -.042 \\
Red & -.969 & -.129 & -.042 & .060 & -.433 & .228 & -.029 \\
HRGB & -.919 & -.122 & .254 & -.184 & -.324 & .131 & .064 \\
Blue & -.828 & -.028 & -.191 & .262 & -.485 & .254 & -.173 \\
Redness index & -.786 & -.114 & -.435 & .368 & -.463 & .301 & -.138 \\
LOI \% & .775 & .176 & .489 & -.350 & .568 & -.180 & .158 \\
Hue Index & .769 & .468 & -.302 & -.160 & .209 & -.055 & -.206 \\
Mo & .755 & .408 & -.170 & -.004 & .208 & .167 & .053 \\
Mn & .122 & .826 & .064 & .007 & .138 & -.110 & -.360 \\
Ba & .089 & .710 & .348 & -.233 & .339 & -.181 & -.356 \\
K & .188 & .648 & -.081 & -.103 & .003 & -.558 & -.443 \\
Cu & .040 & .643 & -.078 & .615 & -.164 & -.129 & -.336 \\
& .033 & .615 & -.114 & .445 & -.299 & -.014 & -.480
\end{tabular}




\begin{tabular}{|c|c|c|c|c|c|c|c|}
\hline $\mathrm{Zn}$ & .320 & .581 & .526 & -.061 & .368 & .081 & -.176 \\
\hline $\mathrm{P}$ & .428 & .493 & .310 & -.160 & .471 & .346 & .112 \\
\hline V & .127 & .137 & .875 & -.263 & .515 & .137 & .129 \\
\hline $\mathrm{Fe}$ & .152 & -.030 & .847 & -.115 & .433 & .283 & .189 \\
\hline $\mathrm{Y}$ & .169 & .079 & .838 & -.265 & .622 & .173 & .125 \\
\hline $\mathrm{Ni}$ & -.170 & .226 & .793 & .188 & .061 & .262 & -.069 \\
\hline Saturation index & -.066 & -.032 & .771 & -.597 & .217 & -.240 & .212 \\
\hline colouration index & .277 & .038 & .720 & -.618 & .390 & -.271 & .221 \\
\hline $\mathrm{Zr}$ & -.118 & -.003 & .720 & .450 & -.051 & .142 & -.033 \\
\hline SRGB & -.446 & -.051 & .682 & -.539 & .001 & -.098 & .197 \\
\hline $\mathrm{Li}$ & -.116 & -.086 & .072 & .898 & -.183 & -.153 & -.096 \\
\hline $\mathrm{Mg}$ & -.233 & .280 & -.072 & .864 & -.381 & -.102 & -.347 \\
\hline $\mathrm{S}$ & -.058 & -.271 & -.156 & .762 & -.100 & .326 & .134 \\
\hline B & .088 & .458 & -.184 & .701 & -.179 & -.148 & -.318 \\
\hline D90 & .450 & -.060 & .135 & -.642 & .369 & .017 & .525 \\
\hline SIRM & .397 & .086 & .254 & -.169 & .969 & -.002 & .013 \\
\hline Xlf & .389 & .114 & .215 & -.149 & .960 & .057 & -.057 \\
\hline Xarm & .262 & .057 & .148 & -.145 & .918 & .048 & -.061 \\
\hline Irm -100mT & .416 & .029 & .223 & -.138 & .867 & .053 & -.054 \\
\hline HIRM & .245 & .165 & .180 & -.146 & .718 & -.075 & .091 \\
\hline $\mathrm{Pb}$ & .482 & .502 & -.038 & -.144 & .505 & -.312 & -.268 \\
\hline $\mathrm{Sr}$ & -.371 & -.137 & .248 & -.106 & -.029 & .840 & .155 \\
\hline $\mathrm{Ca}$ & -.372 & -.332 & .002 & -.251 & -.138 & .740 & .352 \\
\hline $\mathrm{Al}$ & .030 & -.012 & -.154 & -.063 & -.037 & -.244 & .176 \\
\hline SSA & -.093 & .309 & -.086 & .160 & .044 & -.060 & -.964 \\
\hline D50 & .079 & -.333 & .171 & -.296 & .160 & .231 & .943 \\
\hline D10 & .020 & -.345 & -.025 & -.089 & -.172 & -.032 & .903 \\
\hline Span & .189 & .328 & -.138 & -.178 & .000 & -.268 & -.829 \\
\hline
\end{tabular}




\section{Classification scheme 1}
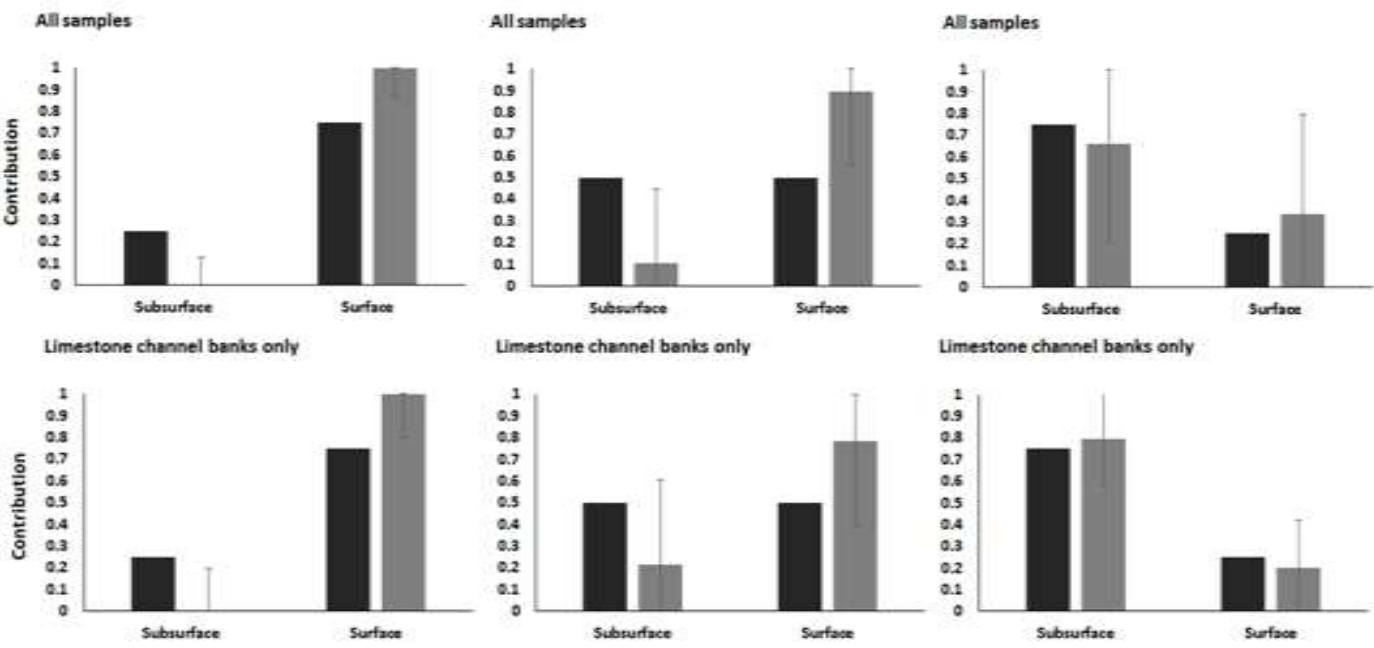

Limestone channel banks only
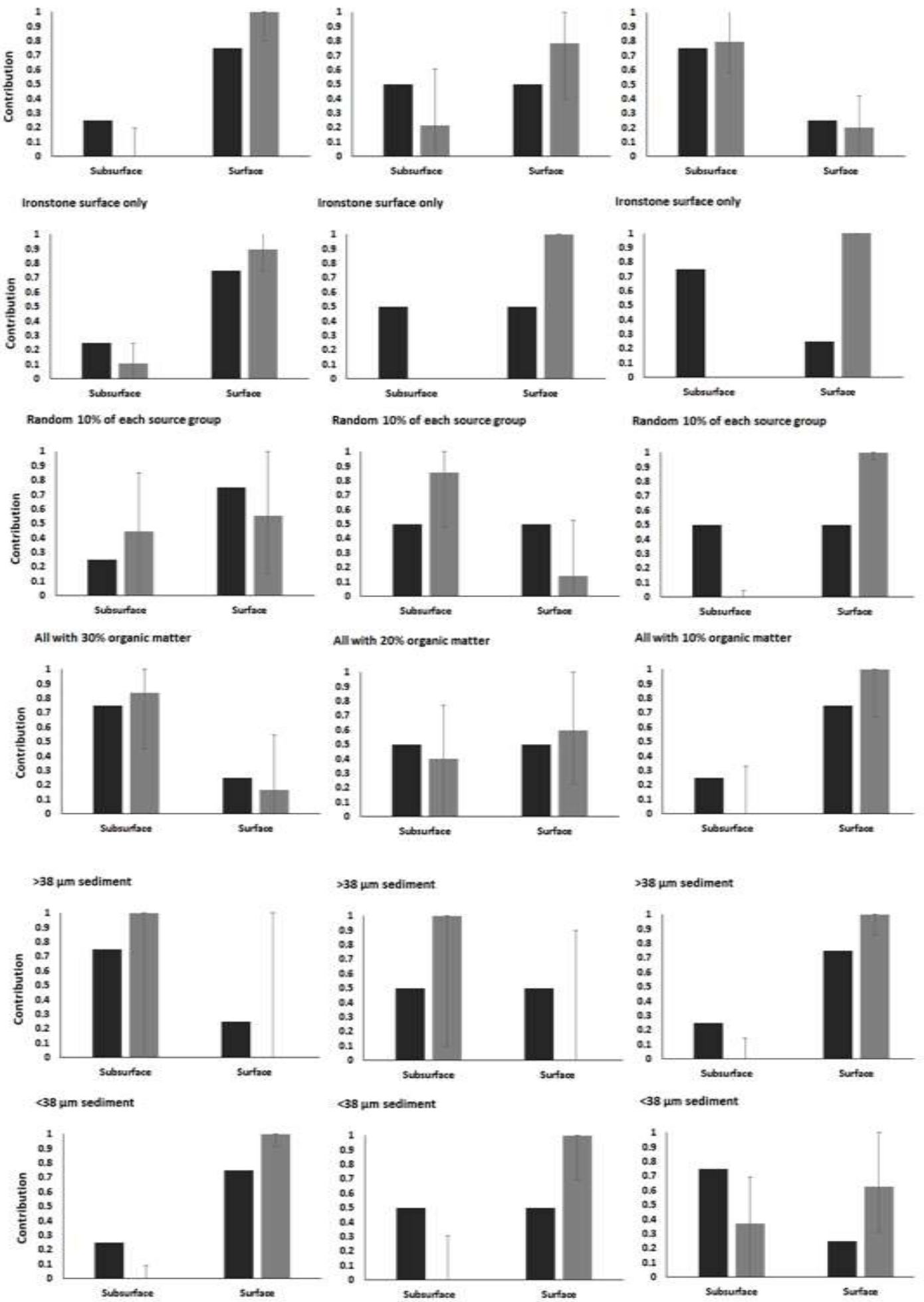


\section{Classification scheme 2}
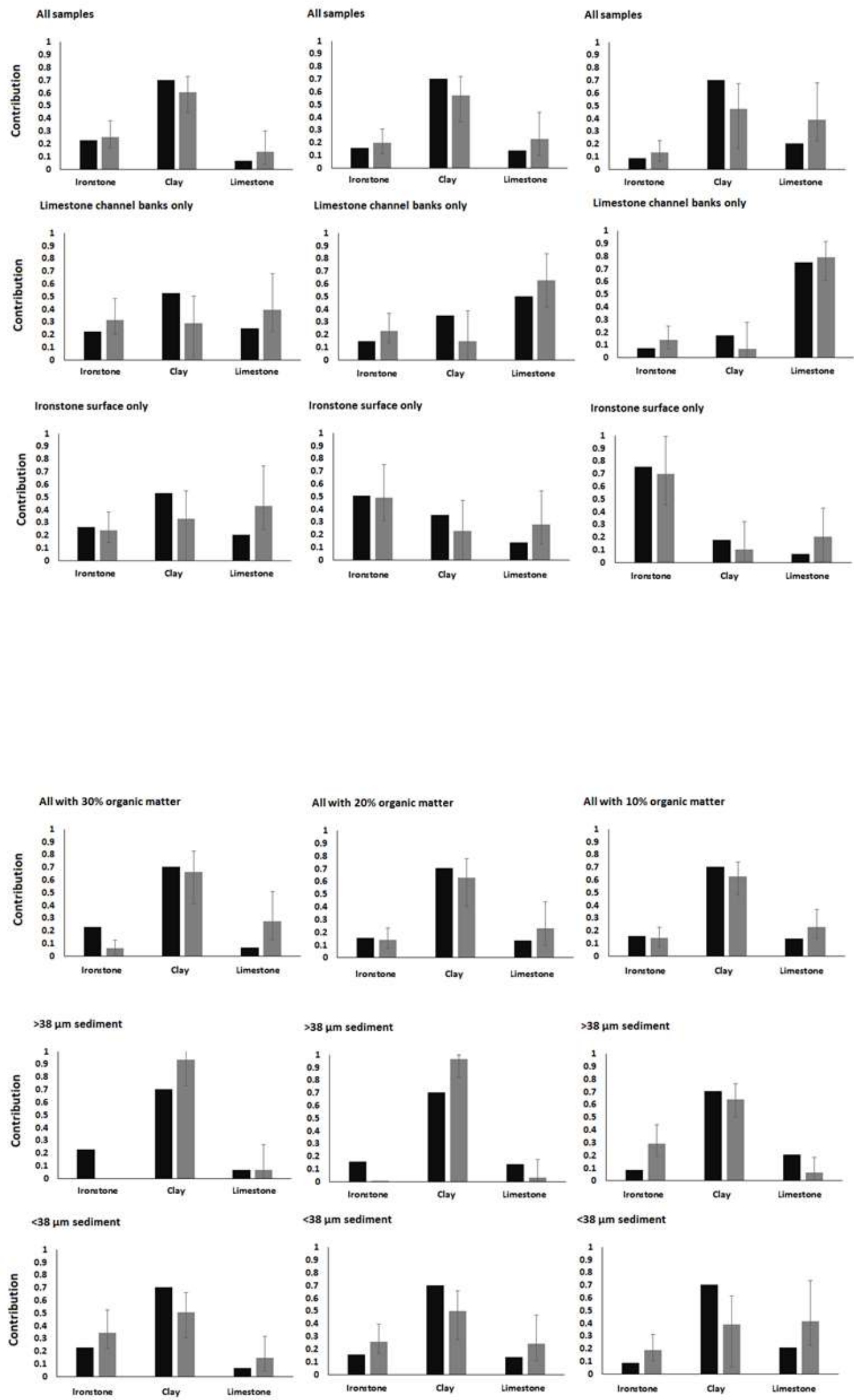
Classification scheme 3
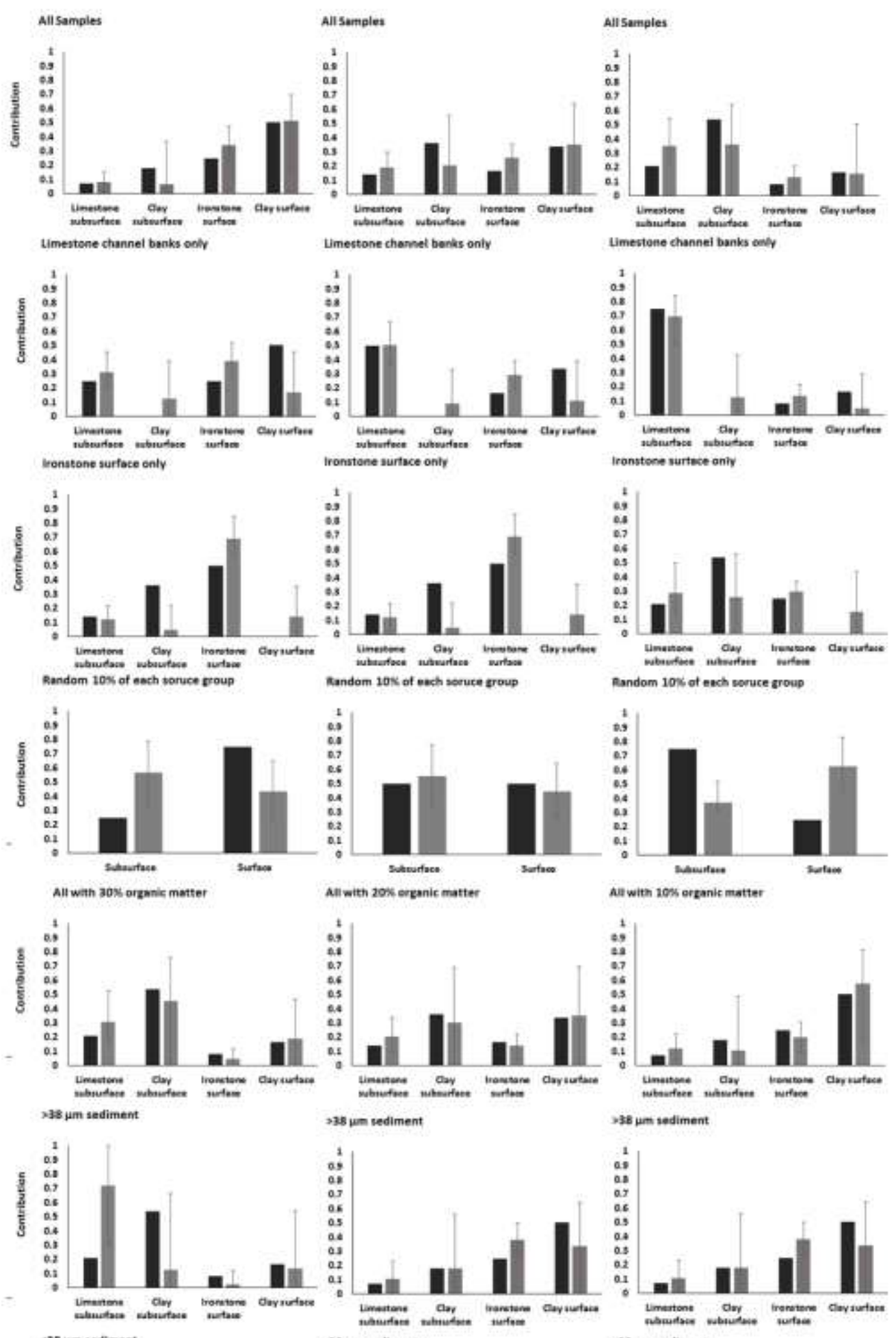

$<38$ un sediment c) um sedimem
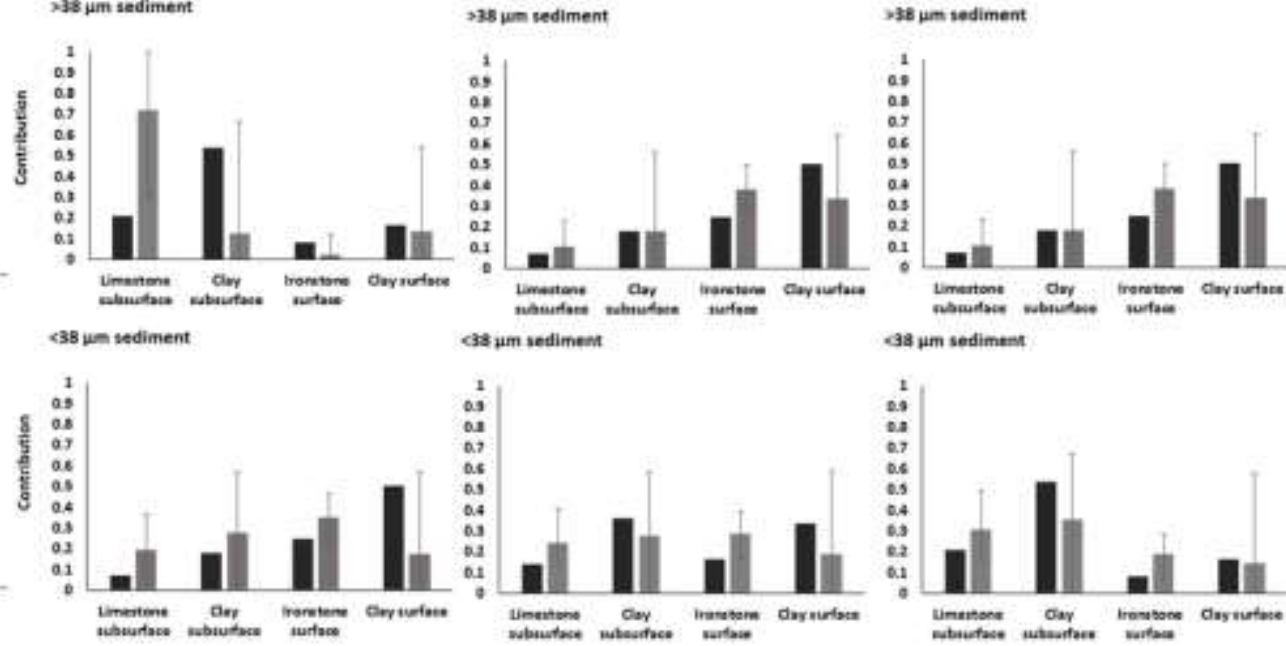
Figure S1: Actual and modelled sediment source contributions to the artificial mixtures. Actual contributions are in dark grey and modelled contributions are in light grey. 
